\title{
Odyssey of life
}

Born to the world

you unfurl your sails, snapping and billowing they harness the power, leading you through the odyssey of life.

Wallowing in calm waters you listen to the rhythm of life.

But, never far away the whish of a breeze to fill your sails, and proudly you cut a swathe through gentle waters.

To'ing and fro'ing you face challenges, adapting with ease. But troubled waters lie ahead, as winds of change bluster and storm clouds gather.

The utmost challenge facing you, your sails battered and torn you falter, struggling for a safe haven to rest your wounded soul.

The storm over, you emerge shaken, but not broken.

And once again you unfurl your sails forging ahead, in your quest to master the seas.

\section{Stefanie Fleischer}

Correspondence to Stefanie Fleischer, Waterford Healing Arts Trust, University Hospital Waterford, Waterford, Ireland; stefanie.fleischer@hse.ie

\section{Competing interests None.}

Provenance and peer review Not commissioned; internally peer reviewed.

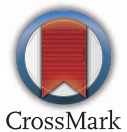

To cite Fleischer S. Med Humanit 2017;43:e12.

Published Online First 29 November 2016

Med Humanit 2017;43:e12. doi:10.1136/medhum-2016-011126 